\title{
Retraction Note to: Inferring Phylogenetic Relationships of Indian Citron (Citrus medica L.) Based on rbcL and matK Sequences of Chloroplast DNA
}

\author{
Ajit Uchoi ${ }^{1}$ - Surendra Kumar Malik ${ }^{2} \cdot$ Ravish Choudhary $^{1} \cdot$ Susheel Kumar $^{3}$. \\ M. R. Rohini ${ }^{1} \cdot$ Digvender Pal $^{1} \cdot$ Sezai Ercisli ${ }^{4} \cdot$ Rekha Chaudhury $^{2}$
}

Published online: 24 October 2019

(c) Springer Science+Business Media, LLC, part of Springer Nature 2019

\section{Retraction to: Biochemical Genetics (2016) 54:249-269 https://doi.org/10.1007/s10528-016-9716-2}

The Editor-in-Chief and the publisher have retracted this article [1] because of significant overlap with previously published articles [2-5]. Ajit Uchoi, Surendra Kumar Malik, Ravish Chaudhary, Susheel Kumar, M.R. Rohini, Digvender Pal, and Sezai Ercisli disagree with the retraction. The publisher was not able to get in contact with Rekha Chaudhury, she did not respond to any correspondence about this retraction.

\section{References}

1. Uchoi A, Malik SK, Choudhary R et al (2016) Inferring phylogenetic relationships of Indian citron (Citrus medica L.) based on rbcL and matK sequences of chloroplast DNA. Biochem Genet 54:249269. https://doi.org/10.1007/s10528-016-9716-2

2. Kumar S, Nair KN, Jena SN (2012) Molecular differentiation in Indian Citrus L. (Rutaceae) inferred from nrDNA ITS sequence analysis. Genet Resources Crop Evol 60:59-75. https://doi.org/10.1007/ s10722-012-9814-X

The original article can be found online at https://doi.org/10.1007/s10528-016-9716-2.

Surendra Kumar Malik

skm1909@gmail.com

Ravish Choudhary

ravianu1110@gmail.com

1 Indian Agricultural Research Institute, Pusa Campus, New Delhi, India

2 Tissue Culture and Cryopreservation Unit, National Bureau of Plant Genetic Resources (NBPGR), Pusa Campus, New Delhi, India

3 Rubber Board Office, Paralakhemundi, Gajapati, Odisha, India

4 Department of Horticulture, Faculty of Agriculture, Ataturk University, Erzurum, Turkey 
3. Jena SN, Kumar S, Nair NK (2009) Molecular phylogeny in Indian Citrus L. (Rutaceae) inferred through PCR-RFLP and trnL-trnF sequence data of chloroplast DNA. Scientia Horticulturae 119:403-416. https://doi.org/10.1016/j.scienta.2008.08.030

4. Penjor T, Yamamoto M, Uehara M, Ide M, Matsumoto N, Matsumoto R, Nagano Y (2013) Phylogenetic relationships of Citrus and its relatives based on matK gene sequences. PLoS ONE 8(4):e62574. https://doi.org/10.1371/journal.pone.0062574

5. Federici C, Fang D, Scora R, Roose M (1998) Phylogenetic relationships within the genus Citrus (Rutaceae) and related genera as revealed by RFLP and RAPD analysis. Theor Appl Genet 96:812822. https://doi.org/10.1007/s001220050807

Publisher's Note Springer Nature remains neutral with regard to jurisdictional claims in published maps and institutional affiliations. 